\title{
2) 電子顕微鏡の立場から
}

a) 網内系の細胞学

神戸医科大学病理学第一講座

家森武夫森芳茂
緒

言

繹内系細胞についての電顕的研究はリンパ節において 最もよく行われている7/8/10/12/23/25). 本邦においても田 中 ${ }^{28)}$ の報告以来, 高木ら ${ }^{26)}$, 森 ${ }^{19}$ ), 細川 ${ }^{13)}$ の報告が 見られる. しかし，脾臟細網細胞については，その構成 細胞の多様性の故に，細胞の同定に困難を伴う事が多 く，あまり報告はみられず，諸外国においてもWeiss ${ }^{33}$ の報告の外は知り得ない。

われわれの教室においても，つとに松浦18) が，結核性 炎症時のリンパ節の微細構造について報告したが，その

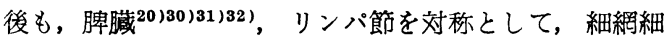
胞の観察を続けて来たので，現在迄に得られた結果を報 告する。

さて網内系の細胞学を論ずるに当っては，先ず命名に 対する立場を明らかにする必要がある．細網細胞乃至組 糡球という同一の名称を使用していても，その研究者に よって必ずしもその対称となる細胞が一定しているもの でないことは，網内系細胞の定義自身に末だ明確な統一 がなされていない点より考えれば当然の結果である．単 に国内的な問題のみに止らず，これが histiocyte， reticulum cell として国際的に用いられる場合におい ては,この問題は更に複雑となる.したがってっこっに われわれの電子顕微鏡による形態学的研究の対称とした 細胞について，予めその立場を明確にしておきたい。

すなわちこ〉に取扱う細胞は，脾およびリンパ節の細 網細胞，皮下結合織内組織球およびリンパ洞乃至静脈洞 内皮であるが，こ>に云う細網細胞は脾およびリンパ節 において，食食能を有する細胞であり，かつ血液由来でな いと考えられるものをさしている，細網線維造成能の有 無については明らかにしていないが，この中明らかに遊 離円形化したような細胞は線維との関係も当然否定出来 るので, むしろ組織球の名が適当かと思われるが，一応 これも細網細胞として扱っている.

更に組織球については，皮下結合織内に増生する良食 能を有する細胞を称しているがこれにおいても細網線 維との関係は未だ明らかにしていない。

リンパ洞内皮または脾静脈洞内皮については,これら の細胞は赤崎によれば典型的細網内皮には含まれないこ
とになるが一応こ〉に加えた．また細網細胞由来につい て, 古来議論の多い形質細胞についても, 若干の知見を 追加したい.

\section{観察材料および方法}

観察に用いた動物は家鬼およびマウスである.脾につ いては正常動物および結核感染家鬼, チフスワクチンま たはネズミチフス菌 S. typhii murium 感染マウス,リ ンパ節は結核感染家鬼およびいろいろの蛋白を接種した 家鬼の膝筒リンパ節を用いた．皮下組織は正常家鬼，チ フスワクチン接種家鬼および結核感染家鬼を用いた。

標本作製にはいずれも1\%オスミウム酸固定, metacrylate 包理を用い，切片は Sjöstrand 型また は Leitz 製 microtome により薄切した。電子染色は 行っていない。使用した顕微鏡は明石 TRS-50, 日立 HU-11 および JEM6TS である.

観 察 結 果

\section{1) 細網細胞}

脾に常在する細網細胞は，電顕所見から次の様に分類 出来る.

a) 成熟型または静止型

胞体の大きさは，概ね $10 \mu$ 前後で不規則な形態を持 つ. 核は類円形で偏在することが多いが，時に不規則な 切れ込みを有するものも見られる. 特にリンパ節におい ては極めて深い不規則な凹凸を有するものが大部分を占 める、核質はびまん性に分布するが，その密度は，リン パ球よりかなり疎で, 染色標本の織細な核網を有する淡 明核に一致する。

小型の核仁が 1〜2 個認められることがある．細畇質 内は小空胞状滑面小胞体がよく発達している. 粗面小胞 体も散在性, 時に限局性に集合して認められる.

中心域には比較的よく発達した Golgi 装置が見られ る. Golgi 装置は主として空胞系よりなり, 膜系の発達 は顕著でないことが多い. 
糸粒体は長楕円形乃至短桿状で一般にリンパ球系に比 しや>小さい. RNP 顆粒は胞体内にびまん性に散在し ている．胞体内には，この外多少とも貪食物に由来する 電子密度の高い構造物が見られる.

b) 食食型，（肥大型）

この型の細網細胞は, 多数の貪食物およびそれに由来 する構造を有するのが特長である.

胞体は著しく大きく，径 $10 \mu$ 前後から $20 \mu$ におよ ぶものも少くない.

核，胞体の構造は，概ね成熟型にひとしいが，肥大し た胞体内に多数の貪食物およびそれに由来する構造を含 むのが特長である.

またこの型の細胞には㳎い Golgi 野が認められるこ とが多く, 空胞, 小胞, および膜系の 3 者が良く発達 した Golgi 装置が 2〜3 群に別れて在存する.また粗 面小胞体の発達も成熟型に比し良好で，索状に集合する ものから内腔がやや拡大し，中等度電子密度を有する無 形性質物質を含むもの迄いろいろのものがあらわれる。

これらの 2 型は, 田中により細網細胞の機能相とし て分類されている細胞に一致する.

c) 幼若型

我々の幼若型細網細胞と呼称している細胞は，胞体の 大きさは $10 \mu$ 以下，細胞質はやや狭く，核は胞体の中 央またはやや偏在して存在する，核質の分布はリンパ球 に比して疎であるが，びまん性に分布し，1〜2個の核 小体を有する事がある．細胞質は上記 2 型に比し，細胞 質内小器官の発達が悪く, 濔蔓性に分布する RNP 顆 粒の中に, やや少数の滑面および粗面小胞体が 分布 し，糸粒体もやや少数である.この細胞質の構造はやや リンパ牙球に近いが，時に大型の食食物を含むことがあ り，この点ではリンパ球系と明らかに異っている.

われわれは，胞体内微細構造において，前記成熟型に 見られるごとき，小器官の分化，発達にそしい点より，

これを幼若型または未分化型と呼んでいる.

正常家㭸またはマウスの脾およびリンパ節に見出され る細網細胞は．主として上記 3 型で，主としてリンパ滤 胞内, 哊索内, 少数は洞内に認められる. 特に幼若型は 滤胞内または鹃直内に存在し，洞内には現われない。何 等かの刺㦸が加えられた際には, 細網細胞の増殖像が認 められる．その際出現する細胞には次のごときものがあ る.

\section{d) 增殖型}

大きさは $10 \mu$ 前後, 成熟型にほぼ等しいが，最も特 長的なのは，大型の核小体を有することである。核は胞 体に比してやや大きい傾向がある．細胞質内には成熟型 と同様な小器官が認められるが，その数はやや少なく， それに比して RNP 顆粒の分布が密である. Golgi 装 置は小形ながら，成熟型に認められるものと同様な，空 胞，小胞および膜系からなるものが $2 \sim 3$ 群認められ る。
しかしこの型の分裂像に遭遇することは比較的稀であ る.

e) リンパ芽球様細胞

大きさ $8 \sim 10 \mu$ 刺軲時のリンパ節および脾のリンパ 滤胞の周辺部にあらわれる。核は類円形で核質の分布 は, 小形リンパ球に比較すれば, かなり疎で, したがっ て核全体の電子濃度もほとんど細網細胞にひとしい，中 型の核小体を $1 \sim 2$ 個有する. 畇体はやや広く, 多数の RNP 顆粒が洧蔓性に分布し, 径 $0.5 \mu$ 前後の長楕円形 ないし 類円形の糸粒体が核周に分布している. 滑面小 胞体および粗面小胞体は，少数見られるが，時に粗面 小胞体が比較的発達のよいものがある.このような微 細構造は,リンパ芽球に一致している. しかしながらっこ の細胞集団中には粗面および滑面小胞体の発達が更によ くその形態が 細網細胞の成熟型に類似したものが 混 じしかもそれらの細胞間には連続的移行があるやに考 えられる. 更に刺㦸に応じて結節性細網細胞增殖栄があ らわれるに先だって, 此較的早期に, 単に滤胞内に於て のみならず, リンパ洞内においても, この細胞の分裂像 が多数に出現し，典型的な細網細胞と考えられるごとき 細胞の分裂像に接することは比較的稀である.したがっ て細網細胞の増殖に際しては, 先に述べた増殖型細網細 胞以外にこのようなリンパ芽球様細胞からの分化も行 われるものとわれわれは考えている．以上がリンパ節な らびに脾において. 共通して認められる細網細胞ならび にそれと関係のある細胞の微細構造である.しかしリン パ節特にそのリンパ洞内には，上記の細胞とは幾分そ の形態を異にした細胞がみられる.すなわち胞体の大き さは $10 \mu$ 前であるが, 細胞質は著しく突起に富み, 時 に隣接する同種の細胞と, 緾絡する傾向を示す，核は凹 凹が多く, 不整形を示す点では, 通常の細網細胞とひと しいが，核小体を認めることはほとんどない，細胞質に は多数の細線維状の構造が認められる.この構造は顕著 なものにおいては全細胞質に湎蔓性に存在するが, 細胞 質外周部には, 小胞状の滑面小胞体が存在し, 内形質に のみ細線維構造が認められるものや，胞体のごく一部の みに限局性に存在するものなど, その程度はいろいろで ある. 細胞質内小器官は, 細線維の発達に反此例してい る.一般にこの種の細胞には, 貪食物およびそれに由来 する構造は諗められないが, 細線維構造と同時に, 貪食 物をも包含しているものも時に見られる.この細胞 が，貪食後変性に陥りつつあるものか，それとも，リン パ洞内にのみ認められることから, リンパ洞内細網組織 と何等かの関係を有するものかは現在の所, 結論するに 至っていない.

\section{2)皮下結合織内組織球}

正常家鬼皮下結合織に存在する組織球の微細構造は,

概ね，次のごときものである.

胞体の大きさは, 長径 $10 \mu$ 前後で, 紡鍾形を示すも 
のを主とするが，細胞質の辺縁には，突起を有するもの が多く，その為に不整形を示すものもみられる．核は長 楕円形，腎形ないしや〉不規則な凹凸を示す，核質はび まん性で, 中等度の密度を示す. 小形の核小体を $1 \sim 2$ 個認めることもあるが，これを欠くものも多い，細胞質 内には，多数の小空胞状滑面小胞体が，びまん性に散在 し, 一部のものは, や>拡大して, 中に高電子濃度性物 質を含むものもある. 粗面小胞体は，原則として認めな いられ，糸粒体は長棈円形ないし長桿状を呈し，長径 $1 \mu$ によぶものもある.

Golgi 装置は中等度に発達し，小空胞および膜よりな り，特に膜系の発達が比較的良好である. 皮下組織にお いては，通常異物に接する機会が少い為，大きな貪食物 を含むことは少いが，少数の食食物，およびそれに由来 する高電子濃度性の顆粒を認める. 墨汁ないしペリカン インキを投与する場合には，これら細胞の滑面小胞体内 には，多数の墨粒子を認める.

結核菌または卯白アルブミンの皮下接種後には，早期 から，皮下結合織内に細胞の増殖があらわれるが, 増殖細 胞の主体をなすのは，正常家槵皮下結合織内の組織球と は，微細形態において相当差を示す細胞であるすすなわ ち円形，棈円形または短紡鍾形で，大きさは 5〜7 $10 \mu$ 前後のいろいろのものがある. 核は一般に切れ込 みを有し，不整形を呈するものが多く，核質の密度も正 常時の組織球に比してや〉高い，核小体も小型ながら明 瞭なものが多い，細胞質はせん細な突起を有するが，全 体としてあまり不規則な不整形を示さない，細胞質内に は, 正常時組織球と同様な系粒体と多数の小空胞状滑面 小胞体がびまん性に散在しているが，滑面小胞体はその 数を増している. Golgi 装置がより発達しているもの も認められるが，その性格は膜を主体とする点で正常時 と異ならない，細胞質にはや〉多数の貪食物を含んでい る.これらの細胞の中には, 粗面小胞体の発達を認める ものもあるのが特長的である.すなわちチフスワクチン 接種家躳に結核菌を微量接種して, や>後期の細胞反尤 に, 形態的には，上記細胞と全く異ならないが，索状粗 面小胞体が，限局性に細胞膜に平行に並列しているもの がある.この様な粗面小胞体の発達したものと, それを 殆んど欠くものとの間には漸進的な移行が認められる.

更に, ワクチン 接種 2 週間後に, 結核感染を行なっ た動物で，極く早期に，円形または紡鍾形の小形細胞が あらわれる.この細胞は, 核の電子密度が高く, 小リン パ球に類似しているが，細胞質はや〉豊富で，小空胞状 滑面小胞体が 比較的多数, びまん性に認められる点で は，小リンパ球とは異なっている. 滑面小胞体の発達が 良好な点では，性格的にはむしろ組織球に近い，われわ れは,これと刺㦸時の組織球との間に移行性を認めるこ とから，これを一応幼若型組織球と呼称しているが, 確 实な結論は今後の研究にまちたい.
この様な刺㦸時に出現する細胞は，その胞体内に，血 液単球に認められる特殊な顆粒を認めない点より, 組織 球と考えられ，これを刺㦸型組織球と呼称する.

3) 脾静脈洞およびリンパ節リンパ洞内皮細胞

脾静脈洞内皮細胞は，断裂性の基底膜栏構造または無 形性の電子密度の高い物質を被覆する秠平な細胞で, 細 胞質は長く伸展している，核は，核質の分布密度がや〉 高く. 小型の核小体を $1 \sim 2$ 個有する. 核存在部以外 の伸展した細胞質内に円形乃至長㭋円形の糸粒体, 小空 胞状滑面小胞体が散在している. Golgi 装置も小型であ るが, 主として空胞および小空胞よりなるものを核に接 して認める. 時に滑面小胞体の内腔が桩大して, 大きな 空胞状を呈する事もある.この内皮細胞は，はく離して も，概ね扁平な原形をとぐめている. 䓹食物を細胞質内 に認めることは，極めて稀である．この様な構造は，一 般血管内皮のそれに近似している. 刺㦸時には, 時に細 胞質は肥大し, 特に滑面小胞体の拡大を認めることがあ る.

リンパ洞内皮は辺縁洞を被覆するものは，その外側 に，基底膜様構造を認めるが，骾洞ではこのような構造 を認めない.内皮細胞の性格は脾静脈洞内皮細胞に近似 しているが，核の電子密度はや>低い，更に一般に細 胞質はや〉片く，核存在部においても，その内腔側 に, 系粒体, 小胞体などの 小器官を認め得る. また Golgi 装置も大型であるが，主として空胞および小空胞 よりなる点では, 脾静脈洞内皮と異ならない. 粗面小胞 体は，時に少数認める事がある.この細胞においても， 苓食物またはそれに由来する構造は稀に少数認めるにす ぎない。

\section{4）幼若形質細胞}

卵白アルブミンを腹腔内に投与感作を行なった家鬼の 足䟲皮下に卵白アルブミンの再接種を行なつた際には, 2〜3 日後膝窩リンパ節内に著明な 形質細胞増殖巣があ らわれる.この増殖巣は, 主としてリンパ節髄質にあらわ れ，皮質リンパ滤胞には認められない。この様な形質細 胞増殖巣を観察して，その幼若型を追及すると次のごと き所見が得られる.すなわち, 最も幼若と考えられる細 胞は, 長径 $10 \mu$ 前後, 核は大型で, 円形ないしや〉四 凸を示し, 核小体も明瞭である. 細胞質内には， RNP 顆粒が極めて密に分布し, 少数の大型の糸粒体を認め る. 小胞体は極めて発達が喜いが, 細長な索状の粗面小 胞体を若干認める. Golgi 装置は, 比較的よく発達し, 空胞系および小空胞系より成る.

この幼若細胞の成熟過程を追及すると，粗面小胞体は 次第にその数を増し, やがて内腔がやや桩大しはじめ る. Golgi 装置も次第にその大きさを増し，遂に核の一 側に巨大な部分を占めるに至る，核は成熟につれて，偏 在する様になり．核質にも車軸状の配列が見られるに至 る. 
この様な所見は，増殖巣の一切片の中においても，い ろいろの形態を兒出すことが出来，漸進的な移行をよく 追及し得る.

\section{総括ならびに考按}

食食作用を基点として眺めた網内系細胞の特長は, 細 胞質内における, 滑面小胞体の良好な発育と云う点に於 て，すべての細胞に共通な性格が認められる. 前述のリ ンパ節ならびに脾葴における細網細胞, 皮下結合織内組 織球は勿論, 既にわれわれの教室で報告した䀒星細胞 ${ }^{17)}$ や，関節滑液膜内組織球㥞細胞 ${ }^{211}$ ，肺胞食細胞において も，この特長は普遍的に認められる。しかしながらその 他の点においては，必ずしも同様な形態を示すとは云え ない.その最も単的な例は, 組織球と細網細胞に招ける 粗面小胞体の発達度の差である.すなわち細織球におい ては，原則として粗面小胞体は存在しないが，リンパ節 ならびに脾蔵の細網細胞には常在している．しかしなが ら，前述のごとく，組織球においても，チフスワクチ ン，または卵白アルブミンによって予め感作が行なわれ た際に，増殖した細胞においては，程度の差こそあれ粗 面小胞体の発達を認める，また細網細胞においても，結 核感染, チフスワクチンまたはチフス菌接種により，粗 面小胞体の発逹は，更に顕著になり，結核性類上皮細胞 に於て，このことが特に明らかであるのは，既に松浦の 発表に見られる通りである．即ち網内系細胞における粗 面小胞体の発達は，動物の感作状態に密接な関連性を有 するかに見える，かく考えれば，リンパ節打よび脾蔵に おける細網細胞に常在的に粗面小胞体の認められること はこれらの藏器が血液およびリンパ液によって絶えず 刺㦸にさらされている環境によるものとも理解出来る. この点においては, 赤崎が Rössle の生理的炎症なる 概念を引用することは充分首肯し得るものである，われ われは現在，この網内系細胞の粗面小胞体に，細胞性抗 体の産生を推測している. 天野4 も先に，いろいろの 知見から, 細網細胞の粗面小胞体に抗体産生能を推測し ている。

さて細網細胞の電顕所見による分類は，つとに田

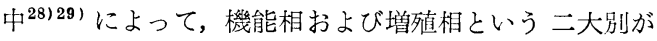
行なわれている. 田中は，機能相を以って細網細胞の貪 食機能ならびに細網線維形成に関与する形態と考え, 増 殖相は，同形成的分裂によって，細網細胞の増殖に与る と共に,リンパ肧球を通じて, リンパ芽球およびリンパ 球形成に関与する形態とみなしている.

われわれは細網細胞を成熟型, 食食型, 幼若型および 増殖型に分類したが，田中の分類と比較すれば，われわ れの成熟型および苓食型は機能相に相当し，増殖型は田 中の増殖相にほら゙近似したものである. しかしわれわれ の幼若型に相当する形態は，田中によれば全く無視せら れているか, 若しくは増殖相またはリンパ球系への移行
の途次に擬せられていると考えられる．しかしわれわれ はこれを，粗面ならびに滑面小胞体の未発達な細網細胞 と見るわけであり，その点では意見は一致しない，われ われの観察では, 細網細胞の増殖時においても, 増殖型の 分裂像に接することは, 比較的少数であるが, 結核感染時 などにおける細網細胞結節の形成にあたつては，それに 先だって，前述のごとくリンパ芽球に近似した細胞の分 裂像を多数認める事が多く，またそれの細網細胞一の移 行を認めうる点より, リンパ芽球様細胞と呼称したもの にも細網細胞増生能を認めたいと考えている．血球発生 について一元論を採る欧米学派が，いろいろの名称で呼 ぶ大リンパ球様細胞が果して電顕的にどの細胞に一致す るかは，疑問の点が多いが，近くは Leiber ${ }^{15)}$ の模式図 に見られる grosse lymphoide Retikulumzellen.は, われわれの所見よりみれば, 必ずしも一顧の洒傎なしと しない感を受ける. 勿論細網細胞に造血能を認めるこれ ら一元論者の考えには, 批判の材料に乏しく論及しえな w.

次に組織球については，梶川は14)，それが粗面小胞 体を灾き，滑面小胞体に豊む特長の外に， $\mathrm{H}$ 顆粒なる特 殊な顆粒を以て, 鑑別の要点としている.われわれの観 察においても，前述のごとく，正常家秉組織球では，そ の特長に, 全く一致している. しかし, 刺軲時において は, 組織球においても，粗面小胞体の発達があり，時に はその層板状配列を見ることも前述の通りである. 刺㦸 時に皮下結合織に増生する細胞については，その形態は 正常組織球とはや>距りがあり,その帰属については, 問 題があろう。われわれは, この細胞が血液単球のすでに 報告せられている微細形態と，若千の差違を示すことを 根拠として,この細胞を組織梂の刺㦸型に擬している.し かし, 特に, 幼若型と呼称した細胞は,その存在部位, 出 現時期から刺㦸型組織球への移行が推定し得られるが, この細胞については，田中はリンパ球様細胞なる名を与 えている，組織球を，細網細胞の環境の差による異った 形態と考えるならば，細網細胞についても，この幼若型 組織球と同様な細胞を求めうるわけであるが，リンパ節 や脾のごとく，リンバ球系細胞の多数存在する部分に おいては，たとえ存在してもその同定は頻る困難であろ う. 光顕的に, 古来小円形単核細胞の名によって呼称せ られて来た，炎症反応に出現する細胞は，この細胞であ ると考えられ，また，皮下組織の炎症巣の位相差頙微鏡 観察によってわれわれが小型単球 ${ }^{8)}$ と呼称して来な細胞 も，この細胞に外ならない，また，赤崎らの局所性刺㦸 下の超生体染色による 遊離小中型細胞もこの細胞に 一致すると ${ }^{33)}$ 考えられる.

細網内皮については, 赤崎 ${ }^{12) 31}$ はこれを細網細胞と は発生的にも，性格的にも全く別個のものと考えてい る. 更に, リンパ洞内皮や脾静脈洞内皮は，滑䯋静洞 内皮や盰の Kupffer 氏星細胞とは異り，元来固有内皮 に属するもので，細網内皮ではないと考えている．田中 
も電顕所見より，リンパ洞内皮は細網細胞とは全く别の 細胞である事を認めている，しかし，Weiss は電顕的 観察によっても，脾静脈洞内皮は，細網細胞の特殊な位 置をとったものであると考えている．われわれの結果で は，田中の結果に全く等しく，明らかに細網細胞と区別 しうるものである. 但し，田中はリンパ洞内皮について は，明らかな基底膜構造を見ないと云うが，われわれの 結果に於ては，リンパ節においては，辺縁洞外縁におい て，脾洞においては，局部的に，明らかに層状分化を示 す基底膜構造を認める部分のある事を指摘したい，しか し，䯋洞および大部分の脾洞においては．不連続な無構 造な基質を認めることは，田中の所見と同様である

細網線維と上述の諸種細胞との関係についてはわれ われは結論的な結果を現在得ていないため, 今後の研究 に期したい。

形質細胞は古来細網細胞起源が提称せられて，現在に おいてもそれを支持する人は多い，天野516)はこれに 対して外膜細胞起源説を唱え，その説は既に Rohr の著 書にも紹介されている. また Rohr ${ }^{22}$ は RHS の名の 下に極めて拡大した網内系の理論を唱えたが，当然その 中には形質細胞をも包合している．しかし，形質細胞の 網内系所属については未だ結論は得られていない，

しかし最近，電子頙微鏡を駆使してこの問題に挑んだ 研究者には細網細胞起源説を唱えるものが多い. 天野門 下の田中はこの問題に対し, リンパ節においては, 形質 細胞の幼若型は，形質芽細胞迄辿ることが出来るが，そ こで細網細胞またはリンパ泼球との連続性が絶たれるこ とを強張し，リンパ節においては外膜細胞起源を否定し てはいるが，細網細胞起源をも認めてはいない，

私の追求した形質細胞増殖巣においては, 前述のごと く, 田中の記載している形質芽細胞より, 更に未分化な 形態を示す細胞を多数に見出した. この細胞と形質細胞 成熟型との間には確実な連続性を認めることが出来る. この幼若細胞を, basophile Stammzelle またはgrosse basophile Lymphoidezelleに擬すれば， 細網細胞起 源を全く否定することは出来ない.しかしながら，われ われの観察では, この幼若細胞の成熟細網細胞一の移行 を現在迄には証明し得ないので結論は今後に期したい.

結侕会

1) 脾臓およびリンパ節の 細網細胞ならびに皮下結 合織内組織球を正常家秉, 被刺㦸状態下の家鬼, マウス を対称として，電子蹎微鏡によって観察した。

2) 細網細胞を, 成熟型, 含食型, 幼若型および増 殖型に分類して，その微細構造を述べた.

3) 細網細胞の増殖は, その増殖型の分裂と同時に, リンパ芽球様細胞の増殖によっても行われると考えられ る.
4 ）皮下組織球には, 原則として, 粗面小胞体の発達 がないが, 刺㦸時にあらわれる刺㦸型組織球には, 粗面 小胞体の層板状発達を示すものがある. また刺㦸時に は, リンパ球様の形態を示す小型細胞が出現することを 確め，私共はこれを幼若型組織球と命名した。

5 ) リンパ節内に増殖する形質細胞の最幼若型は, 極めて未分化な形態を示すが，細網細胞系との移行は未 だ立証し得ない。

終りに臨み, 本シムポシュウム参加の栄を与えられた 勝沼総会会長, 赤崎教授を始め, 幹事の諸先生に潹甚な る謝意を表します。また本䂨究に協力せられた。全教室 員の労苦に東心より感謝致します。

\section{参考文献}

1）赤崎兼義：日病会誌，41：1 (1952)

2) 赤崎兼義：日網内誌，1：7 (1961)

3) 赤崎兼義, 綿貫 勤：日本血液学全書 1 , 形能学. 丸善, 東京, 1963, p 630

4) 天野重安：日血会誌，15：840（1962)

5) 天野重安, 平田もとえ, 藤井淳子：日病会 誌, $34 ： 26$ (1944)

6) 天野重安, 田中春高：日血会誌, $19: 738$ (1956)

7) Bernhard. W. and N., Glanboulan : Ciba Foundation Symposium on Cellular Aspects of Immunity, J. \& A. Churchill, London, 1960, p. 98

8) 菩提寺幹人：日体質誌，21：35 (1956)

9) Braunsteiner, H. : Blood, $12: 278$ (1957)

10) Fresen,O. und H.J. Wellensiek : Verh. Dtsch. Ges. Path, 42 ; 353, (1959)

11）後藤ツヤ：神医大紀，19；1096，(1960)

12) 堀江昭夫： 福岡医学誌, $52 ； 135$ (1961)

13) 細川恭子： 東京慈恵会医誌， $76 ； 1274$ (1960)

14) 梶川欽一郎： 最新医学, $13 ； 1042$ (1958)

15) Leiber, B. : Der menschliche Lymphknoten, Urban \& Schwarzenberg, München und Berlin, (1961)

16) Low, F.H. and J.A. Freeman : Electron microscopic atlas of normal and leukemic human blood, McGraw Hill, N.Y., (1958)

17) 松尾梅雄： 神医大紀, $15 ; 99$, (1959)

18）松浦 覚：同上 $13 ; 549$, (1958)

19) 森 喜美 : 九州血液研究同好会誌, 10 : 221,238 , (1960)

20）森 芳茂, 福水 瞭：日網会誌, $1 ; 77$, (1961) 
21）尾立竹次郎： 神医大紀, $19 ； 216$, (1960)

22) Rohr, K. : Das menchlsiche Knochenmark, Georg Thieme, Stuttgart, (1960)

23) Seon S. H. : Am. J. Anat., $109 ; 183$ (1961)

24）清水 孝：神医大紀, $12 ; 663$, (1958)

25) Sarensen, G. D. : Am. J. Anat., 107 ; 73, (1960)

26）高木文一, 鈴木昭男, 安田寛基 他 : 日病会 誌, $47 ； 612$, (1958)

27） 田中春高：日血会誌，20；237，(1957)
28) 田中春高：Ann. Report, Inst. Virus Res., Kyoto Univ., Series A, Vol. 1, 87, 1958

29) 田中春高：日本血液学全書, 1. 形態, 丸 善, 東京, 1963, 364

30）家森武夫：日病会誌，52；35，(1963)

31）家森武夫： 結核, 37 ；394，(1962)

32）家森武夫, 佐々木正道, 森 芳茂, 松浦 覚 : 最新医学, $17 ； 1022$, (1962)

33）綿貫 勤：日病会誌, $51 ; 114$, (1962)

34) Weiss, L. : J. B. B. C., 3 ; 599, (1957) 


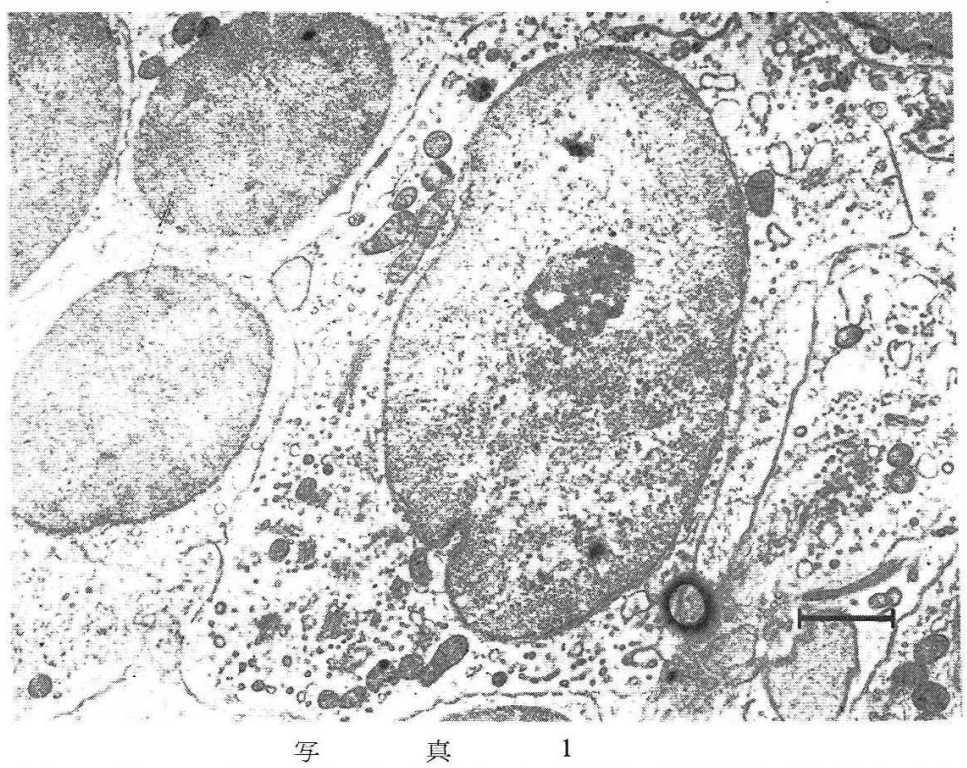

成熟型細網細胞（リンパ節），滑面小胞体は小空胞状のもを多数に認めるが，粗面 小胞体は少数である.

$\times 15,000$

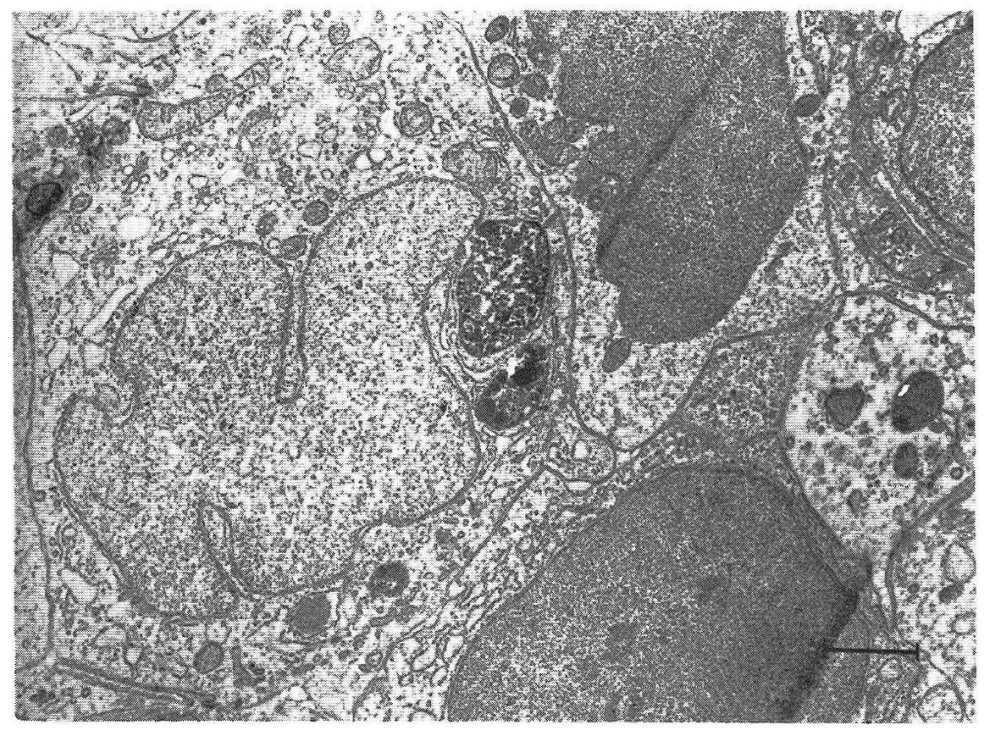

写

真

2

舍食梨細網細胞（リンパ節）卵アルブミン投与後のもので，大きな食食体と同時 に前の写点に比し粗面小胞体がやっ多い. $\times 15,000$ 


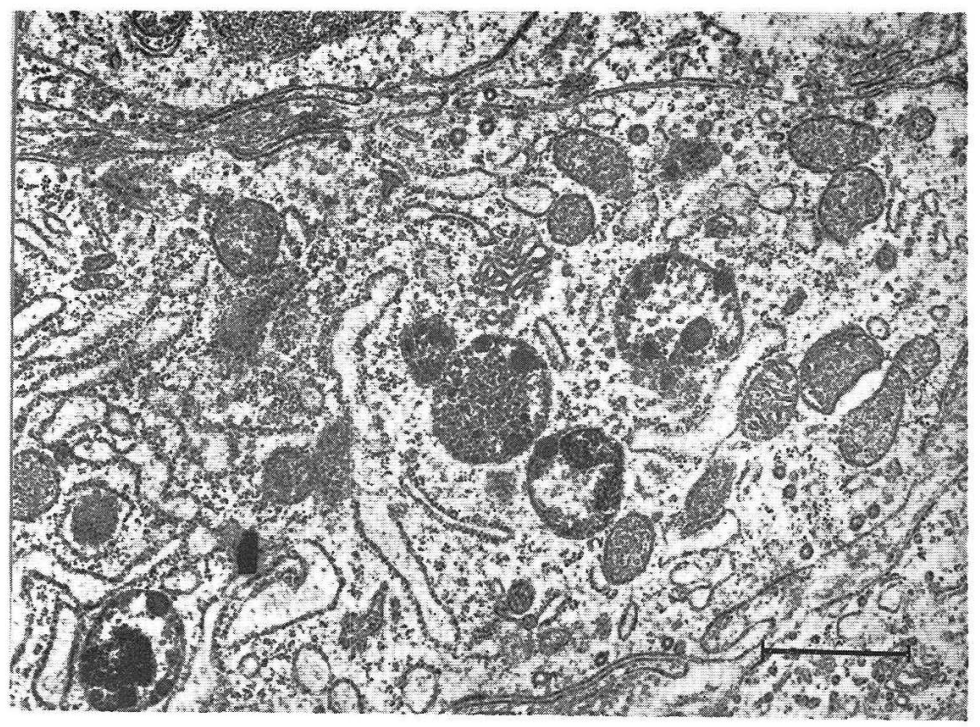

写

真 3

食食型細胞細胞の部分像，粗面小胞休が拡大し，中に低電子湄度性物質を満たし ている. $\times 22500$

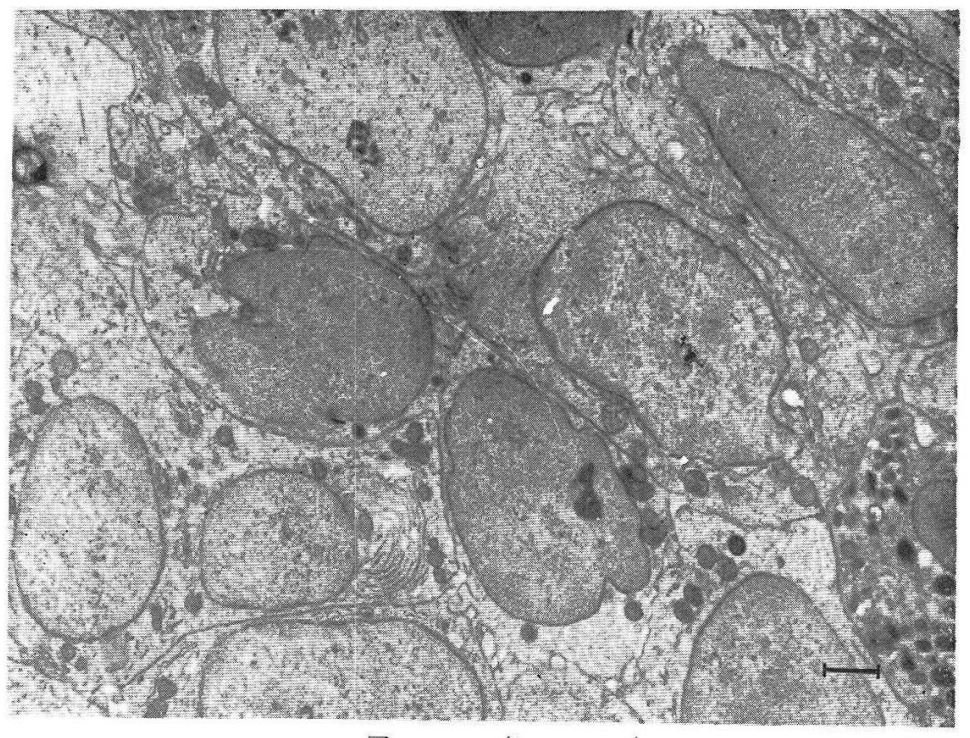

写

点

4

結椟菌感染後の脾内增殖性病変, 層状粗面小胞体を有する細網細胞と一見リンパ 芽球様細胞を認める. $\times 8000$ 

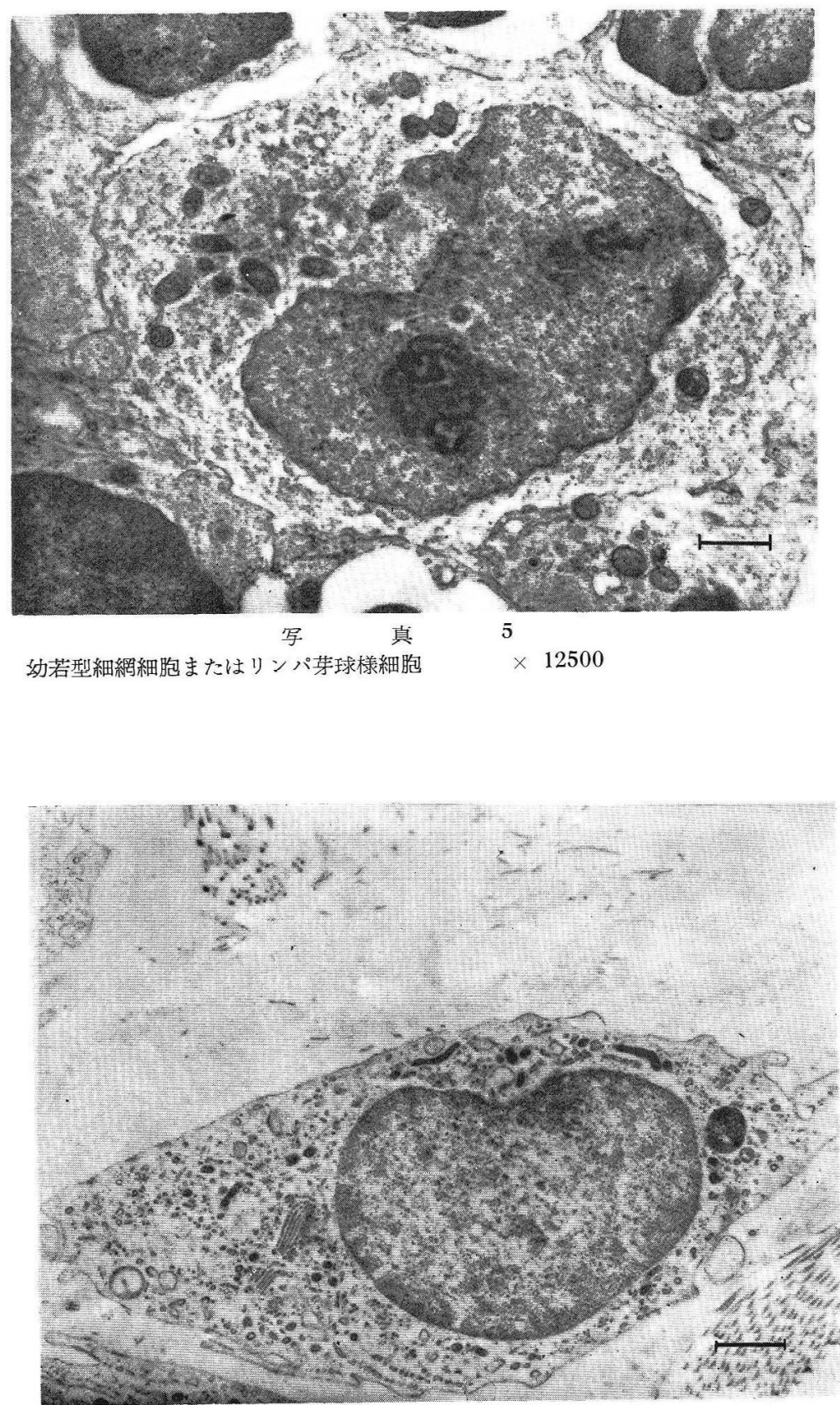

写

真

6

静止型組織球，小空胞状滑面小胞体を多数に認める. Golgi 装置は膜系が著明で ある。 $\times 12500$ 


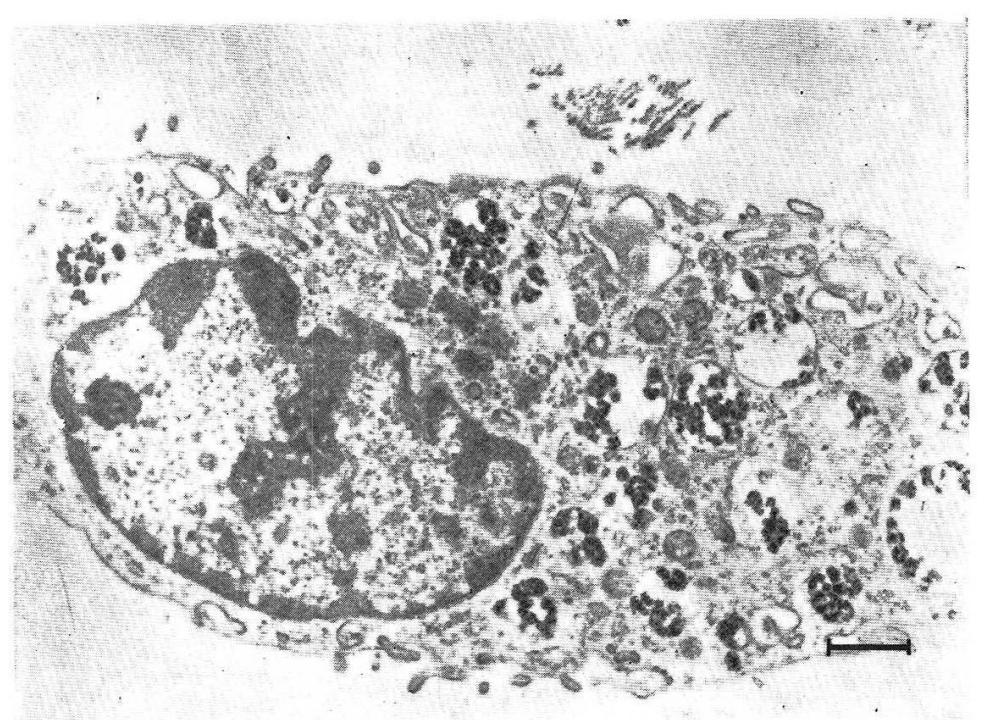

写真 7

食食型組織球，拡大した滑面小胞体中に多数の炭未を入れている. $\times 12,500$

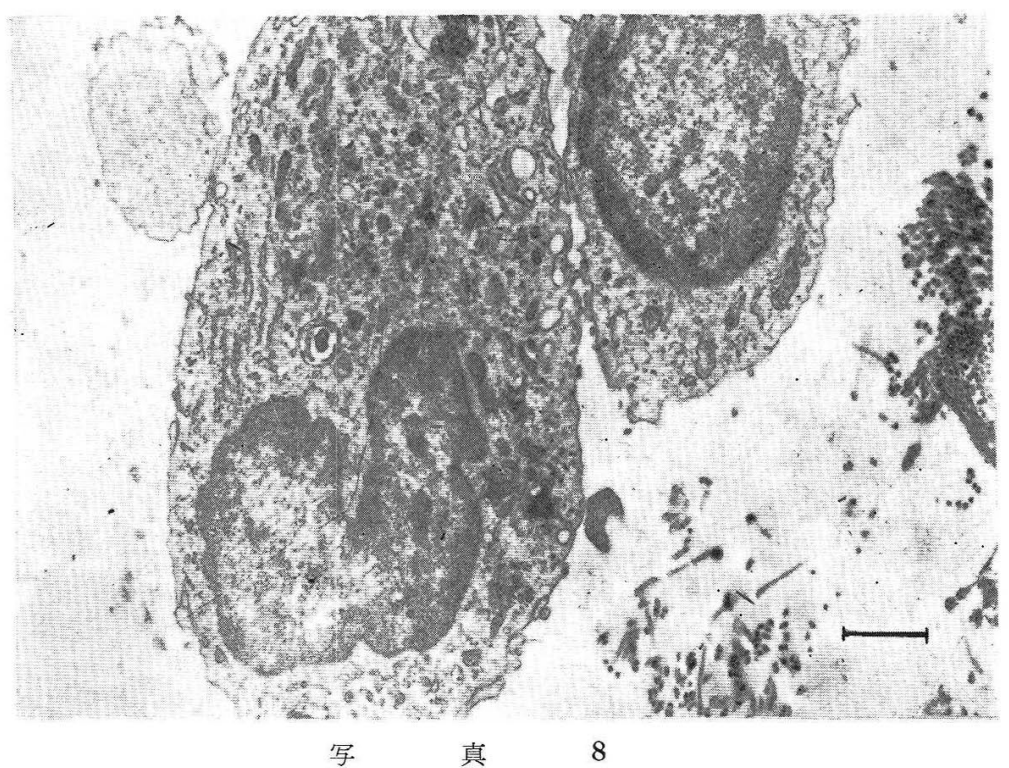

刺战型組織球. 胞体は電子密度がや〉高く, 粗面小胞体の発達が認められる. 

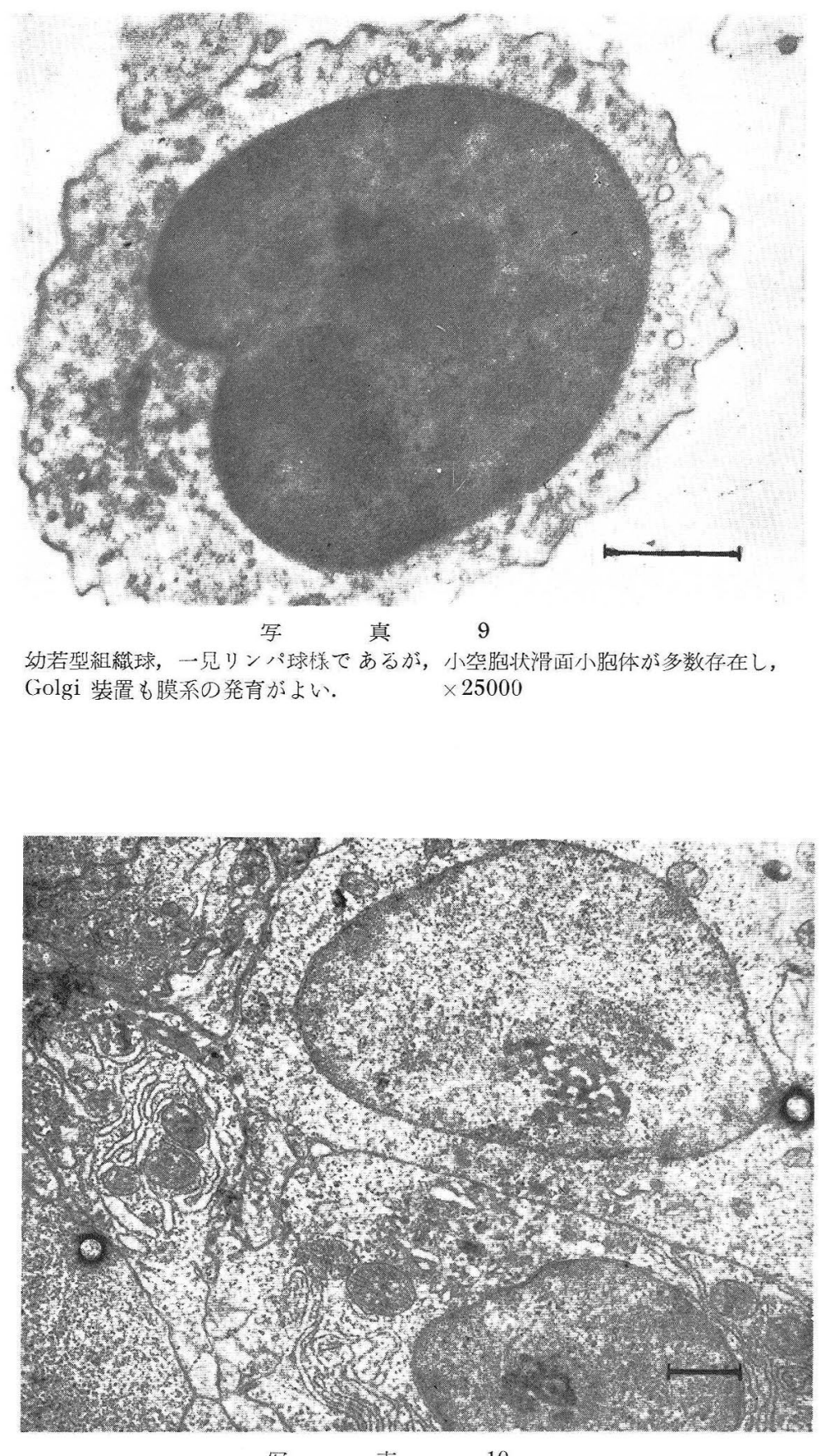

写

真

10

形質細胞増殖㮺，粗面小胞体の発達度の異る形質芽細胞が相接して認められる. $\times 12500$ 


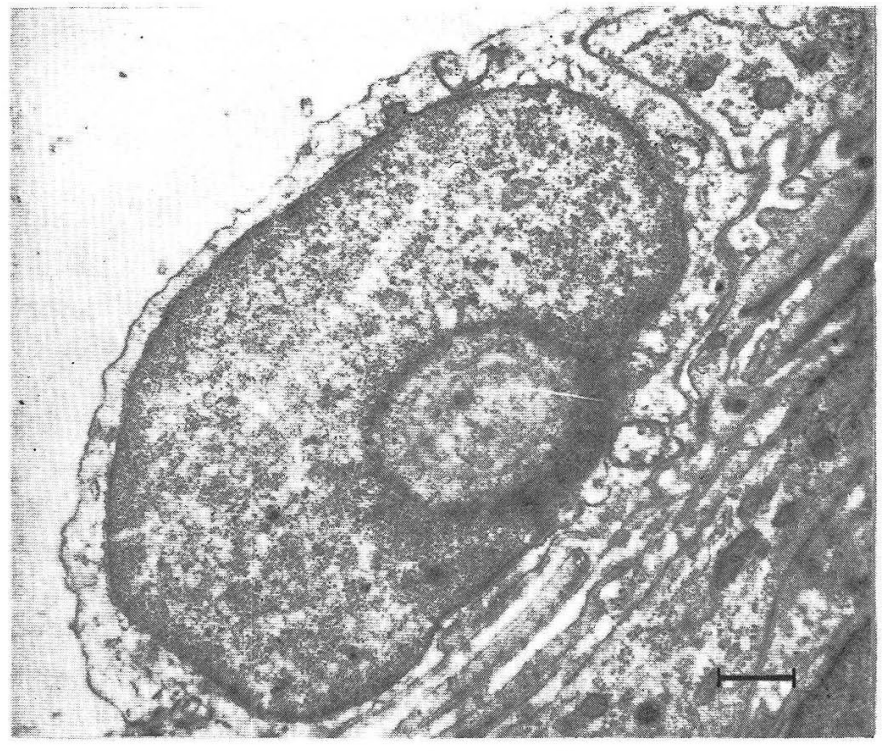

写

11

リンパ節辺縁洞内皮細胞，基底膜構造を有している.

$\times 1050$

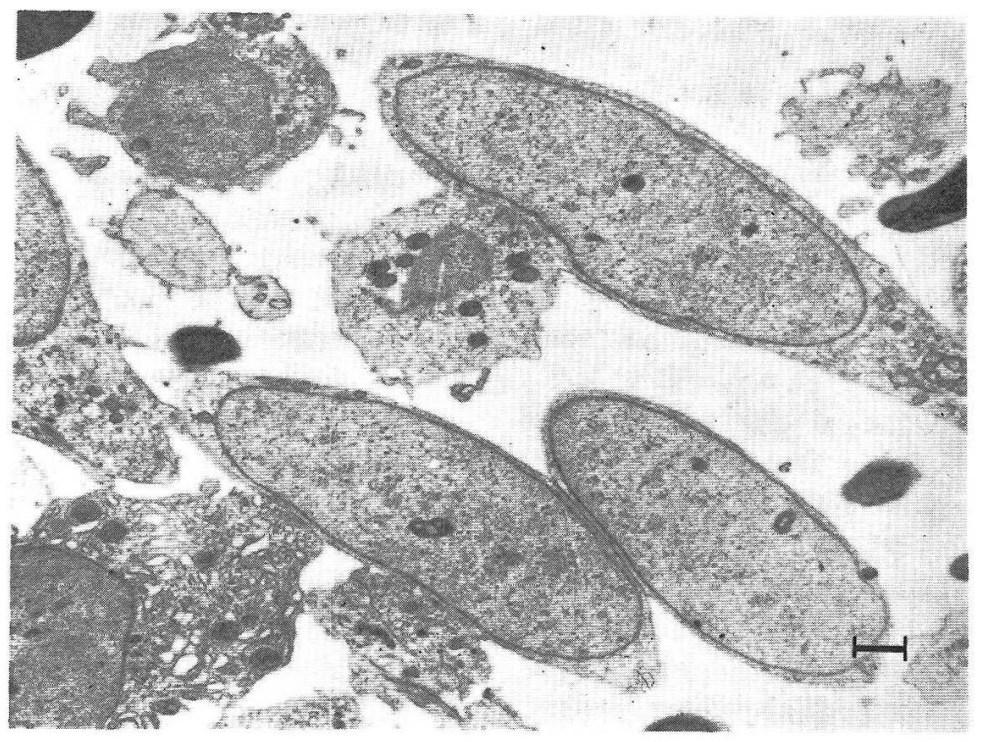

罙

真

12

脾静脈洞内皮，而平で細胞質分伸展てている。 